\begin{tabular}{|c|c|c|}
\hline Case Reports i & \multicolumn{2}{|c|}{ Case Rep Gastroenterol 2014;8:282-285 } \\
\hline Gastroenterology & $\begin{array}{l}\text { DOI: } 10.1159 / 000368301 \\
\text { Publisned onlline: Uctober 3, } 2014\end{array}$ & $\begin{array}{l}\text { (c) } 2014 \text { S. Karger AG, Basel } \\
\text { 1662-0631/14/0083-0282 } \$ 39.50 / 0 \\
\text { www.karger.com/crg }\end{array}$ \\
\hline & \multicolumn{2}{|c|}{$\begin{array}{l}\text { This is an Open Access article licensed under the terms of the Creative Commons } \\
\text { Attribution-NonCommercial } 3.0 \text { Unported license (CC BY-NC) (www.karger.com/OA- } \\
\text { license), applicable to the online version of the article only. Distribution permitted for non- } \\
\text { commercial purposes only. }\end{array}$} \\
\hline
\end{tabular}

\title{
Is It Barrett's Esophagus or Gastric Heterotopia?
}

\author{
Zeynel Mungan \\ Koc University School of Medicine, Istanbul, Turkey
}

\section{Key Words}

Barrett's esophagus · Gastric heterotopia - Gastroesophageal reflux disease

\begin{abstract}
Columnar epithelium in the distal part of the esophagus is generally related to Barrett's esophagus. Barrett's esophagus is a well-known premalignant lesion for adenocarcinoma of the esophagus. Therefore, its diagnosis and surveillance are important. Columnar epithelium in the esophagus other than Barrett's esophagus can be gastric heterotopia, which generally takes place in the upper part of the esophagus and is named inlet patch. The presence of gastric metaplasia in the distal part of the esophagus is rare and can cause misdiagnosis. Therefore, its differentiation from Barrett's esophagus is important. Here we present a case of gastric heterotopia located in the distal part of the esophagus that caused reflux-like symptoms and needed differentiation from Barrett's esophagus.

(c) 2014 S. Karger AG, Basel
\end{abstract}

\section{Introduction}

Barrett's esophagus is a complication of gastroesophageal reflux disease. It is a wellknown premalignant lesion and can cause adenocarcinoma of the distal esophagus. Therefore, its diagnosis is important and it needs endoscopic surveillance. Endoscopically, Barrett's esophagus can be defined as the displacement of the squamocolumnar junction proximal to the gastroesophageal junction [1], but for a full definition, two criteria must be fulfilled: first, the documentation of columnar epithelium in the distal part of the esophagus, and second, the histopathology of that columnar epithelium must reveal intestinal metaplasia. Although some authors believe that gastric cardiac-type epithelium in the esophagus might also predispose to cancer and thus might be considered 'Barrett's esophagus', most authorities still require the presence of intestinal metaplasia for an unequivocal diagnosis $[2,3]$. 
Mungan: Is It Barrett's Esophagus or Gastric Heterotopia?

Heterotopic gastric mucosa has been described in different parts of the gastrointestinal tract from the tongue to the rectum [4]. There have also been reported cases where it was seen in the gallbladder or cystic duct, the omphalomesenteric duct, the umbilicus and the liver [5-7], but the organ most commonly involved is the esophagus. Heterotopic gastric mucosa of the esophagus is generally located in the cervical part of the esophagus and termed inlet patch [4]. An inlet patch is widely considered to be congenital [4, 8]. Although it can be responsible for laryngeal reflux symptoms, pain and dysphagia $[4,8,9]$, the majority of patients with an inlet patch are asymptomatic and detected incidentally during the evaluation for other gastrointestinal complaints $[4,8,10]$. The presence of Helicobacter pylori in this area is not rare [11], and heterotopic gastric mucosa can be responsible for the development of webs, strictures, ulcers, fistula and, exceedingly rarely, adenocarcinoma [4].

The presence of gastric heterotopia in the esophagus other than in the cervical part is not well known. Here we present a case of esophageal gastric heterotopia that was located in the distal part of the esophagus and needed differentiation from Barrett's esophagus.

\section{Case Report}

A 31-year-old female presented to our hospital with reflux-related symptoms like daily heartburn and, rarely, dysphagia. She was symptom free with proton pump inhibitor (PPI) treatment. Her main reason for visiting our hospital was to get another opinion, because of her concerns related to cancer risk. She had a diagnosis of Barrett's esophagus and had been on surveillance for the last 5 years. She was symptom free with PPI treatment during the surveillance period.

We performed an upper gastrointestinal endoscopy, which revealed an inlet patch in the upper part of the esophagus (fig. 1). Additionally, there was a 3-cm-long, circular, columnar, epithelial segment - between 35-38 cm from the incisors - and the distal part of this segment bordered $2 \mathrm{~cm}$ of squamous epithelium (fig. 2). Biopsies showed acid-secreting, oxyntic-type, glandular, gastric epithelium, there was no intestinal metaplasia or dysplasia, and her test was negative for $\mathrm{H}$. pylori.

We have followed her for another 2 years now. She is still on PPI and has no esophageal or extraesophageal reflux-related symptoms.

\section{Discussion}

Columnar epithelium in the distal part of the esophagus is generally related to Barrett's esophagus. Barrett's esophagus is a well-known premalignant lesion for adenocarcinoma. Therefore, its diagnosis is important. The diagnosis of Barrett's esophagus is based on a suspicion during an endoscopic examination raised by the presence of columnar epithelium in the distal part of the esophagus, and it needs a histopathological confirmation, i.e. the presence of intestinal metaplasia [3]. In Barrett's esophagus, columnar epithelium extends from the stomach up to the gastroesophageal junction into the esophagus [3]. It looks like a continuation of gastric mucosa. But in our case, columnar epithelium was not the continuation of gastric mucosa, it was clearly separated from the stomach by $2 \mathrm{~cm}$ of squamous epithelium. Histopathological examination did not show any intestinal metaplasia or Goblet cells, which are important for the diagnosis of Barrett's esophagus [12]. There was also an inlet patch in our patient, which can indicate that both lesions are congenital and not refluxrelated as in Barrett's esophagus. 
Mungan: Is It Barrett's Esophagus or Gastric Heterotopia?

On the base of information from the literature, we reevaluated the findings in our case as gastric heterotopia and not Barrett's esophagus. This is a rare condition, but it can be found in cases of misdiagnosed Barrett's esophagus as in our patient.

We believe that our patient does not have gastroesophageal reflux disease, but that her reflux-like symptoms are related to acid secretion of the gastric heterotopia in the esophagus. We advised her to continue with her PPI treatment since it was controlling her symptoms. An ablation of the gastric heterotopia's area can be discussed. However, we did not try it because of the lack of support in the literature. Neoplastic transformation in gastric heterotopia is exceedingly rare; therefore, in contrast to Barrett's esophagus, gastric heterotopia has not been accepted as a premalignant lesion [4]. But the inlet patch has been accepted as a premalignant lesion; however, we do not have any information on wide arearelated gastric heterotopia in the esophagus because it is very rare. Therefore, we do not know if surveillance is necessary or not in such a case.

In conclusion, we are presenting a case of gastric heterotopia that is located in the distal part of the esophagus and has been misdiagnosed as Barrett's esophagus. This type of gastric heterotopia can also cause reflux-like symptoms, which resolved very well with PPI treatment in our patient.

\section{References}

1 Wang KK, Sampliner RE; Practice Parameters Committee of the American College of Gastroenterology: Updated guidelines 2008 for the diagnosis, surveillance and therapy of Barrett's esophagus. Am J Gastroenterol 2008;103:788-797.

2 Riddell RH, Odze RD: Definition of Barrett's esophagus: time for a rethink - is intestinal metaplasia dead? Am J Gastroenterol 2009;104:2588-2594.

-3 American Gastroenterological Association, Spechler SJ, Sharma P, et al: American Gastroenterological Association medical position statement on the management of Barrett's esophagus. Gastroenterology 2011;140:1084-1091.

-4 Von Rahden BH, Stein HJ, Becker K, Liebermann-Meffert D, Siewert JR: Heterotopic gastric mucosa of the esophagus: literature-review and proposal of a clinicopathologic classification. Am J Gastroenterol 2004;99: 543-551.

5 Gorlin RJ, Kalnins V, Izant RJ Jr: Occurrence of heterotopic gastric mucosa in the tongue. J Pediatr 1964;64: 604-606.

-6 Martinez-Urrutia MJ, Vasques Estevez J, Larrauri J, Diez Pardo JA: Gastric heterotopy of the biliary tract. J Pediatr Surg 1990;25:356-357.

7 Heo YS, Jeong SY, Son SW, Kim I, Seo SH: Heterotopic gastric mucosa in the umbilicus. Ann Dermatol 2010;22:223-225.

8 Chong VH: Clinical significance of heterotopic gastric mucosal patch of the proximal esophagus. World J Gastroenterol 2013;19:331-338.

-9 Akbayir N, Sökmen HM, Caliş AB, Bölükbaș C, Erdem L, Alkim C, Sakiz D, Mungan Z: Heterotopic gastric mucosa in the cervical esophagus: could this play a role in the pathogenesis of laryngopharyngeal reflux in a subgroup of patients with posterior laryngitis? Scand J Gastroenterol 2005;40:1149-1156.

10 Akbayir N, Alkim C, Erdem L, Sökmen HM, Sungun A, Başak T, Turgut S, Mungan Z: Heterotopic gastric mucosa in the cervical esophagus (inlet patch): endoscopic prevalence, histological and clinical characteristics. J Gastroenterol Hepatol 2004;19:891-896.

-11 Alagozlu H, Simsek Z, Unal S, Cindoruk M, Dumlu S, Dursun A: Is there an association between Helicobacter pylori in the inlet patch and globus sensation? World J Gastroenterol 2010;16:42-47.

12 Spechler SJ, Souza RF: Barrett's esophagus; in Feldman M, Friedman LS, Barndt LJ (eds): Sleisenger and Fordtran's Gastrointestinal and Liver Disease, ed 9. Philadelphia, Saunders Elsevier, 2010, pp 727-733. 
Mungan: Is It Barrett's Esophagus or Gastric Heterotopia?

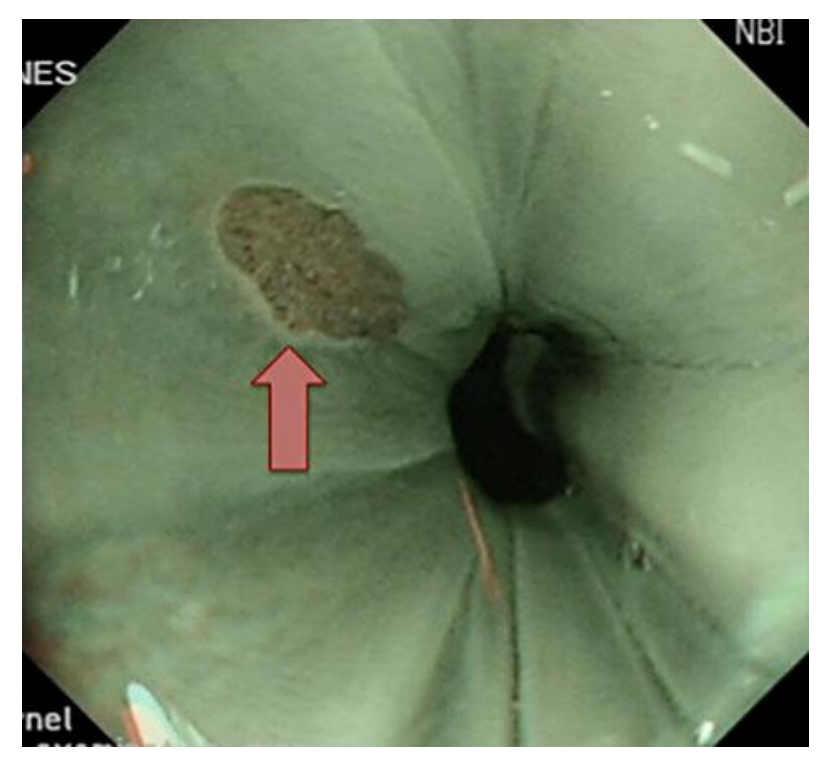

Fig. 1. Inlet patch (arrow) in the cervical part of the esophagus (the picture was taken with narrow-band imaging).

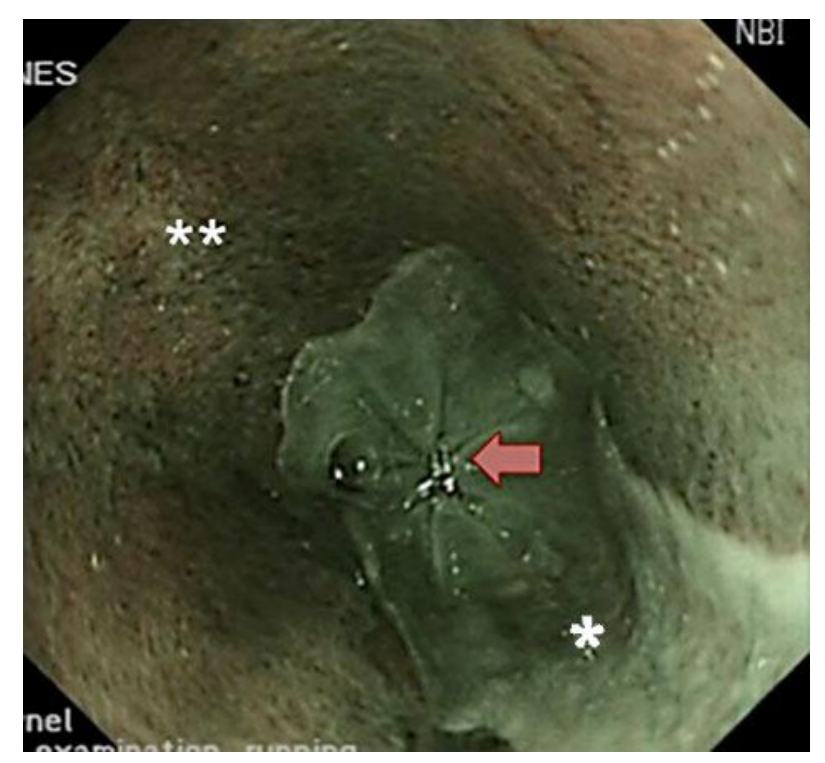

Fig. 2. Gastric heterotopia in the distal part of the esophagus. The whitish area is squamous epithelium (one asterisk), the salmon-colored area is columnar epithelium (two asterisks). Histopathologic examination showed acid-secreting, oxyntic-type, glandular, gastric epithelium (the picture was taken with narrow-band imaging). The arrow points at the gastroesophageal junction. 